\title{
Research Paper Marketing channels and price spread of banana in Chikkaballapur district of Karnataka
}

See end of the paper for authors' affiliations

Correspondence to :

P.S. DHANANJAYA

SWAMY

Department of

Agricultural Economics,

University of Agricultural

Sciences, G.K.V.K.,

BENGALURU

(KARNATAKA) INDIA

Email: danaps610@

gmail.com

\section{Paper History :}

Received : 25.07.2014;

Revised : 18.12.2014

Accepted : 05.01.2015

\section{B. NAVEEN, M.S. JAYARAM, P.S. DHANANJAYA SWAMY, G.B. RAMESH AND D.V. RAGHAVENDRA}

\begin{abstract}
The study was conducted to assess the production and marketing of banana in Chikkaballapur district of Karnataka during the period of 2012-13. The primary data were obtained from the 60 farmers, villager level traders, wholesalers, retailers and vendors. The secondary data were collected from the Directorate of Horticulture and concerned officers of the respective district. The results revealed that, three important marketing channels were identified in the study area. The main players in channel-I were producer, village level trader, wholesaler, retailer and consumer, in channel-II: producer, village level trader, retailer, consumer whereas in Channel-III: producer, village level trader, vendor, consumer. The share of producer in the consumer rupee was higher (50.90\%) in channel-III, as compared to channel-II (46.80\%) and channel-I (41.59\%). Farmers preferred the channel-I, because farmers relished (received) the cash immediately after the sale of the produce to village level trader at the farm level itself. Further, in channel-I, the risk of violent price fluctuation in open market could be avoided.
\end{abstract}

KEY WORDS : Banana, Marketing channels, Price spread

HOW TO CITE THIS PAPER : Naveen, B., Jayaram, M.S., Swamy, P.S. Dhananjaya, Ramesh, G.B. and Raghavendra, D.V. (2015). Marketing channels and price spread of banana in Chikkaballapur district of Karnataka. Internat. Res. J. Agric. Eco. \& Stat., 6 (1) : 18-22. 